\title{
PEMAHAMAN ORANG TUA MENGENAI URGENSI BERMAIN DALAM MENINGKATKAN PERKEMBANGAN SOSIAL ANAK USIA DINI
}

\author{
Novia Rahmadianti \\ Universitas Pendidikan Indonesia Kampus Cibiru \\ Email : noviarahm08@upi.edu
}

\begin{abstract}
ABSTRAK
Artikel ini merupakan kajian literatur yang terkait dengan pemahaman orang tua mengenai urgensi bermain yang dapat meningkatkan aspek perkembangan sosial pada anak usia dini. Lingkungan sekitar anak khususnya orang tua memiliki peran yang sangat penting bagi perkembangan anak, orang tua yang paham mengenai pentingnya bermain bagi anak akan dapat membantu perkembangan anak berkembang dengan baik. Bermain merupakan kebutuhan bagi anak karena anak belajar sambil bermain, salah satu aspek perkembangan yang dapat berkembang melalui bermain yaitu aspek perkembangan sosial. Bermain dapat melatih keterampilan sosial pada anak seperti kerjasama, berbagi dengan sesama, menghargai sesama, tolong menolong, menumbuhkan rasa empati, menjadi pemimpin yang baik, tanggung jawab dan jujur. Banyak manfaat yang didapat oleh anak ketika bermain selain melatih keterampilan sosial, anak juga akan mendapat pengetahuan dan pengalaman baru melalui bermain. Maka dari itu orang tua sebagai lingkungan pertama anak perlu memahami pentingnya bermain bagi anak usia dini, agar orang tua dapat membantu perkembangan anak berkembang secara optimal.
\end{abstract}

Kata Kunci: Orang Tua; Bermain; Perkembangan Sosial.

\begin{abstract}
ABSTRACK
This article is a literature review related to parents' understanding of the urgency of play that can improve aspects of social development in early childhood. The environment around children, especially parents have a very important role for the development of children, parents who understand the importance of play for children will be able to help children develop properly. Play is a necessity for children because children learn while playing, one aspect of development that can develop through play is the aspect of social development. Playing can train social skills in children such as cooperation, sharing with others, respecting others, helping each other, fostering empathy, being a good leader, responsibility and honesty. Many benefits are obtained by children when playing in addition to practicing social skills, children will also get new knowledge and experience through play. Therefore parents as the child's first environment need to understand the importance of playing for early childhood, so that parents can help children develop optimally.
\end{abstract}

Kata Kunci: Parents; Play; Social Development.

\section{PENDAHULUAN}

Bermain merupakan salah satu kebutuhan anak yang harus terpenuhi, karena anak usia dini sedang dalam masa keemasan dimana perkembangan dan pertumbuhan anak sedang berkembang sangat pesat. Maka dari itu lingkungan sekitar anak harus banyak memberi stimulus pada anak agar perkembangan anak berkembang dengan optimal, stimulus yang diberikan dapat melalui bermain. 
Dengan bermain anak akan mendapat keterampilan baru dan memiliki fungsi bagi pertumbuhan dan perkembangan anak (Pujiati, 2015; Khasanah, dkk. 2011). Lingkungan sekitar anak sangat mempengaruhi perkembangan anak seperti Menurut Vygotsky (dalam Danoebroto, 2015, hlm. 195) tentang Zone of Proximal Development (ZPD) adalah "jarak antara kemampuan siswa untuk melakukan tugas di bawah bimbingan orang dewasa dan atau dengan kolaborasi teman sebaya dan pemecahan masalah secara mandiri sesuai kemampuan siswa". Menurut Vygotsky pembelajaran terjadi disini karena kemampuan anak akan didorong melalui interaksi sosial yaitu ZPD.

Namun kurangnya pemahaman orang tua terhadap pentingnya bermain salah satu faktor yang menjadi kendala bagi aspek perkembangan pada anak usia dini. Saat ini banyak orang tua yang menganggap bahwa bermain akan mengganggu proses belajar pada anak, sebagain besar orang tua hanya menuntut anak untuk mempersiapkan pendidikan selanjutnya saja. Padahal lingkungan utama yang dapat membantu perkembangan anak berkembang secara optimal adalah lingkungan keluarga. Selain itu, banyak manfaat yang akan didapat ketika anak bermain salah satunya yaitu dapat mengembangkan aspek perkembangan sosial pada anak. Dengan bermain anak akan sering berkomunikasi dengan lingkungan sekitarnya yang membuat perilaku sosial anak berkembang dengan baik. Adhani dan Hidayah (2014, hlm. 139) mengatakan bahwa perilaku sosial pada anak usia dini ini diarahkan untuk pengembangan sosial yang baik. Banyak sekali manfaat yang didapat dalam bermain bagi perkembangan sosial anak, maka dari itu penting sekali orang tua memahami urgensi bermain terhadap anak usia dini.

Dari permasalahan diatas penulis ingin melakukan penelitian berupa studi literatur untuk mengetahui bagaimana pemahaman orang tua terhadap urgensi bermain pada anak usia dini serta pemahaman orang tua terhadap perkembangan sosial pada anak usia dini. Dilakukannya studi literatur ini diharapkan dapat memberikan informasi kepada pembaca khususnya orang tua mengenai urgensi bermain pada anak usia dini, memahami bagaimana perkembangan sosial pada anak usia dini melalui bermain.

\section{METODE PENELITIAN}

Penelitian merupakan sebuah penelitian kajian literatur dengan menelaah beberapa jurnal yang terkait dengan permasalahan yang akan dibahas yaitu mengenai bermain. Hasil dari jurnal yang telah ditelaah ini akan digunakan untuk mengetahui bagaimana pemahaman orang tua terhadap urgensi bermain dalam mengembangakan perkembangan aspek sosial pada anak usia dini.

\section{PEMBAHASAN}

\section{Orang Tua}

Keluarga dalam lingkungan anak usia dini memiliki peran yang penting bagi anak, karena keluarga merupakan 
pondasi untuk anak belajar dan mengembangkan aspek perkembangannya. Seperi menurut Fadlillah (dalam Novrinda, dkk. 2017, hlm. 41) bahwa lingkungan keluraga adalah lingkungan awal bagi seorang anak, segala tingkah laku maupun perkembangan yang muncul pada diri anak akan mencontoh pada kedua orang tuanya. Maka dari itu, orang tua bertanggung jawab dalam pendidikan anak dan mejadi panutan atau tauladan anak agar perkembangan dan pertumbuhan anak akan berkembang secara optimal. Sejalan dengan pendapat Wibowo, 2012 (dalam Novita, dkk. 2016, hlm. 23) bahwa anak adalah anugerah dan amanah dari Allah SWT maka orang tua berkewajiban dalam menjaga, medidik dan mengarahkan mereka agar dapat berkembang secara optimal dengan potensi yang dimilikinya.

\section{Urgensi Bermain}

Bermain sudah menjadi dunianya anak, bermain bukan hanya menjadi kesenangannya saja namun sudah menjadi kebutuhan untuk memenuhi kepuasannya dan perkembangan anak. Bermain adalah kegiatan yang dilakukan oleh anak dalam memenuhi kebutuhannya dan menimbulkan kesenangan atau kepuasan (Trinova, 2012; Istiarini, 2014). Bermain juga dapat mengembangkan aspek perkembangan anak salah satunya yaitu aspek perkembangan sosial, menurut Tedjasaputra, 2001 (dalam Istiarini, 2014, hlm. 150) mengungkapkan "bermain dapat mengembangkan bermacam-macam aspek perkembangan anak salah satunya adalah aspek sosial, belajar komunikasi dengan temannya untuk mengemukakan isi pikiran dan perasaannya". Dengan bermain anak dapat bersosialisasi dan memberikan kesempatan kepada anak untuk bereksplorasi, berekspresi, berinteraksi serta belajar secara menyenangkan. Ifrianti (2015, hlm. 155) mengatakan bahwa suatu kegiatan yang disebut bermain harus ada lima unsur di dalamnya, yaitu:

a. Mempunyai tujuan, yaitu permainan itu sendiri untuk mendapat kepuasan.

b. Memilih dengan bebas dan atas kehendak sendiri, tidak ada yang menyuruh ataupun memaksa.

c. Menyenangkan dan dapat dinikmati.

d. Mengkhayal untuk mengembangkan daya imajinasi dan kreativitas.

e. Melakukan secara aktif dan sadar.

Kelima unsur tersebut dapat membuat bermain anak menjadi lebih menyenangkan, jika anak bermain dalam keaadan menyenangkan maka anak akan dapat berkesplorasi secara kreatif dengan mudah. Sejalan dengan pendapat Froebel (dalam Pratiwi, 2017, hlm. 111) bermain sebagai bentuk kegitan belajar adalah bermain yang kreatif dan menyenangkan.

Ketika anak bermain cenderung akan mengurangi sifat egosentris pada anak bahkan anak akan sering berbagi dengan teman yang lain (Rohmah, 2016; Kuswanto, 2016). Egosentris adalah memandang sesuatu hanya dengan sudut pandang dirinya sendiri dan tidak dapat membedakannya 
dengan sudut pandang orang lain (Mu'min, 2013; Rohmah, 2016). Dengan bermain juga anak dilatih dalam rasa tanggung jawabnya, kejujuran, bekerja sama dengan kelompok serta melatih kedisiplinan pada anak.

Pada dasarnya anak sudah memiliki kemampuan sosial seperti yang sudah dijelaskan, kemampuan sosial tersebut ada sejak anak dalam kandungan dan akan terus berkembang hingga dewasa. Perkembangan sosial selain memang sudah ada pada diri anak juga dipengaruhi oleh lingkunga sekitarnya. Sejalan dengan pendapat John Locke (dalam Magta, 2013, hlm. 224) bahwa anak seperti kertas putih, baik buruknya anak dipengaruhi oleh lingkungan. Maka dari itu, orang tua sebagai lingkungan pertama anak perlu memberikan pengaruh yang positif terhadap perkembangan sosial anak salah satunya dengan memahami urgensi bermain yang dapat berpengaruh pada perkembangan sosial anak.

\section{Perkembangan Sosial Anak Usia Dini}

Perkembangan sosial pada anak usia dini sangat dipengaruhi oleh lingkungan yaitu lingkungan keluarga, sekolah dan masyrakat yang ada di sekitar anak itu sendiri. Perkembangan sosial adalah kemampuan berperilaku baik dengan teman sebaya, orang tua serta masyarakat agar dapat menyesuaikan diri (Hurlock dalam Jamila, 2019; Mayar, 2013). Pemberian pengalaman yang positif yang diberikan oleh lingkungan kepada anak akan membantu perkembangan sosial anak dalam beradaptasi dengan lingkungannya, terutama lingkungan keluarga (orang tua) karena orang tua adalah lingkungan pertama yang anak untuk berinteraksi.

Pada saat anak bermain dengan teman sebaya nya anak akan sharing mengenai pengetahuan atau pengalamannya. Sejalan dengan pendapat Mayar (2013, hlm. 460) bahwa perkembangan sosial sebagai proses belajar untuk menyesuaikan diri terhadap norma, moral, dan tradisi. Ciriciri perkembangan Anak usia dini dari usia 3-4 tahun menurut Sujiono, 2009 (dalam Mayar, 2013, hlm. 461) adalah:

1. Usia 3 tahun: 1) Bereaksi terhadap orang lain. 2) Menikmati pada saat bergaul dengan anak-anak lain. 3) Dapat memelihara keterlibatan dengan anak yang lain untuk suatu periode yang sangat pendek 4) Mampu berbagi tanpa perlu membujuk. 5) Menunjukkan kemampuan yang sangat kecil untuk menunda kepuasaan. 6) Dapat meniru tindakan dari orang lain. 7)Mulai untuk melibatkan diri pada permainan yang parallel.

2. Usia 3-4 tahun: 1) Menjadi lebih sadar akan diri sendiri. 2) Mengembangkan perasaan rendah hati. 3) Menjadi sadar akan rasial dan perbedaan seksual. 4) Dapat mengambil arah, mengikuti beberapa aturan. 5) Memiliki perasaan yang kuat kearah rumah dan keluarga. 6) Menunjukkan suatu perubahan dalam hal perasaan atau pengertian 
dari kepercayaan pada diri sendiri. 7) Bermain parallel; mulai bermain permainan yang memerlukan kerja sama. 8) Memiliki teman bermain khayalan.

3. Usia 5-6 tahun: 1) Menyatakan gagasan yang kaku peran jenis kelamin. 2) Memiliki teman baik, meskipun untuk jangka waktu yang pendek. 3) Sering bertengkar tetapi dalam waktu yang singkat. 4) Dapat berbagi dan mengambil giliran. 5) Ikut ambil bagian dalam setiap kegiatan pengalaman di sekolah. 6) Mempertimbangkan setiap guru merupakan hal yang sangat penting. 7) Ingin menjadi yang nomor satu. 8) Menjadi lebih posesif terhadap barang-barang kepunyaannya.

Untuk mengembangakan perkembangan sosial pada anak usia dini perlu dukungan dari lingkungan. Faktor yang dapat mempengaruhi perkembangan sosial pada anak usia dini yaitu lingkungan keluarga, keharmonisan keluarga dan perlakuan orang tua serta harapan orang tua terhadapa anak dapat mempengaruhi perkembangan sosial anak. Kemudian faktor lingkungan diluar rumah seperti teman sebaya, guru, hubungan anak dengan orang dewasa dan keamanan juga dapat membantu perkembangan sosial pada anak (Mayar, 2013; Pebriana, 2017).

Jika perkembangan sosial anak diberikan dukungan oleh lingkungan sekitarnya maka anak akan dapat mengembangkan ketermapilan sosial untuk beradaptasi dengan mudah terhadap lingkungan sekitarnya.
Keterampilan sosial adalah kemampuan dan kecakapan dalam mengatur emosi, pikiran melalui komunikasi, kerja sama, berbagi dan berinteraksi dengan lingkungan sesuai dengan norma yang berlaku (Setiawan, 2016; Perdani, 2014). Keterampilan sosial dapat diperoleh melalui teman sebaya, maka dari itu anak usia dini harus diberikan kebebasan yang cukup untuk bermain baik dilingkungan rumah maupun lingkungan sekolah. Menurut Jenice J. Beaty, 1998 (dalam Siska, 2011, hlm. 33) bahwa keterampilan sosial atau prosocial behavior mencakup beberapa perilaku, seperti: a) Empati yang ada dalam diri anak dan mengekspresikan perasaannya dengan memberikan perhatian kepada orang lain dan dapat merasakan perasaan yang dirasakan oleh orang lain. b) Perilaku murah hati dan dermawan yang ada didalam diri anak ditunjukan melalui anak yang mau berbagi sesuatu kepada orang lain. c) Perilaku kerja sama, anak dapat mengikuti perintah secara sukarela dan dapat bergantian atau menunggu giliran. d) Perilaku saling membantu yang ada didalam diri anak, seperti anak dapat membantu orang lain ketika sedang mengalami kesulitan dan membutuhkan bantuan.

\section{Penelitian Terdahulu Terkait Bermain Untuk Mengembangkan Aspek Sosial Anak}

Berdasarkan beberapa hasil penelitian terdahulu terkait dengan bermain untuk meningkatkan aspek sosial pada anak dapat dijelaskan, penelitian yang dilakukan oleh Isbayani, 
Sulastri \& Tirtayani (2015) dengan menggunakan metode penelitian tindakan kelas (PTK). Subjek penelitian ini adalah anak kelompok A PAUD ABC Singaraja dengan jumlah anak 16 yaitu 11 anak perempuan dan 5 anak laki-laki, variabel dari penelitian ini yaitu metode outbond sebagai variabel bebas dan keterampilan sosial sebagai variabel terikat. Hasil dari penelitian ini menyatakan bahwa bermain dengan metode outbond ini dapat melatih keterampilan sosial pada anak karena banyak permainan yang mengharuskan anak untuk menunggu giliran, mematuhi aturan, kerjasama (teamwork), toleransi. Berikut hasil dari penelitian dengan menggunakan metode outbond: (a) bersabar menunggu giliran total hasil observasi mencapai persentase siklus I mencapai $73 \%$ atau sekitar 14 anak sesuai harapan dari 20 anak, dan pada siklus II mencapai 90\%, (b) Menunjukan sikap toleran dapat bekerjasama dalam kelompok pada siklus I mencapai persentase $72 \%$ atau sekitar 14 yang sesuai harapan dari 20 anak, dan pada siklus II mencapai $91 \%$, (c) berbagi alat main pada siklus I mencapai persentase $71 \%$ atau 17 anak yang sesuai harapan dari 20 anak, dan pada siklus II mencapai 91\%, (d) memberikan kesempatan main pada teman siklus I mencapai persentase $67.5 \%$ atau 18 anak yang sesuai harapan dari 20 anak, dan pada siklus II mencapai $93 \%$.

Kemudian hasil penelitian yang terkait dengan bermain lainnya yaitu dilakukan oleh Pujiati (2015) menggunakan metode penelitian tindakan kelas (PTK) atau Classroom Action Research (CAR). Subjek penelitian ini adalah peserta didik kelompok B dengan jumlah 20 anak terdiri dari 9 anak perempuan dan 11 anak laki-laki. Penelitian ini terdiri dari dua siklus, ada sepuluh kali pertemuan di setiap siklusnya. Hasil dari penelitian tindakan kelas ini yaitu di siklus pertama peserta didik sudah dianggap mampu dalam melakukan keterampilan sosial, kemudian peneliti melakukan siklus kedua. Pada siklus kedua ini terjadi peningkatan keterampilan sosial pada anak usia dini seperti anak yang sabar menunggu giliran, mengalah kepada teman, menghargai pendapat orang lain dan dapat bermain bersama.

Berdasarkan hasil penelitian terdahulu diatas, dapat dikatakan bahwa bermain dapat mengembangkan aspek sosial pada anak. Maka dari itu lingkungan sekitar anak baik orang tua, guru, masyarakat harus dapat memahami urgensi bermain bagi anak usia dini agar dapat memfasilitasi anak dan membantu perkembangan sosialnya.

\section{SIMPULAN}

Bermain adalah suatu kebutuhan bagi anak, karena dengan bermain dapat memberikan banyak manfaat bagi anak seperti membantu mengembangakan aspek perkembangan anak dan mendapat pengetahuan baru. Anak belajar dan mendapatkan pengetahuannya melalui bermain. Perkmabangan sosial anak dapat berkembang memlalui bermain, karena dengan bermain anak akan belajar untuk 
Novia Rahmadianti. PEMAHAMAN ORANG TUA MENGENAI URGENSI BERMAIN DALAM MENINGKATKAN PERKEMBANGAN SOSIAL ANAK USIA DINI. Early Childhood : Jurnal Pendidikan. Vol. 4 No. 1, Mei 2020

mematuhi aturan atau norma yang berlaku, bekerjasama dengan teman sebaya, tolong menolong serta menghargai pendapat orang lain.

Maka dari itu lingkungan anak khususnya orang tua sebagai lingkungan pertama anak harus dapat memfasilitasi kegiatan bermain anak agar anak mendapatkan manfaat dari kegiatan bermain yang dilakukannya.

\section{DAFTAR PUSTAKA}

Adhani, D. N. (2014). Peningkatan Keterampilan Sosial Anak Melalui Permainan Tradisional Ular-Ularan. Jurnal PG-PAUD Trunojoyo, 1 (2), 76-146.

Danoebroto, S. W. (2015). Teori Belajar Konstruktivis Piaget dan Vygotsky. Indonesian Digital Journal of Mathematics and Education, 2 (3), 191-198.

Ifrianti, S. (2015). Implementasi Metode Bermain Dalam Meningkatkan Hasil Belajar IPS di Madrasah Ibtidaiyah. Jurnal Pendidikan dan Pembelajaran Dasar, 2 (2), 150-169.

Isbayani, N. S., Sulastri, N. M., \& Tirtayani, L. A. (2015). Penerapan Metode Outbond Untik Meningkatkan Keterampilan Sosial Emosional Anak. e-Journal PGPAUD Universitas Pendidikan Ganesha, 3 (1), 1-11.
Istiarini, R. (2014). Peningkatan Kemampuan Berbicara Melalui Bermain Balok. Jurnal Pendidikan Usia Dini, 8 (1), 145-154.

Jamila, S. (2019). Pengembangan Sosial-Emosional Anak Melalui Metode Role Playing (Bermain Peran) di Kelompok B Anak Usia Dini. Pelangi: Jurnal Pemikiran dan Penelitian Islam Anak Usia Dini, 1 (1), 84-101.

Khasanah, I., Prasetyo, A., \& Rakhmawati, E. (2011). Permainan Tradisional Sebagai Media Stimulasi Aspek Perkembangan Anak Usia Dini. Jurnal Penelitian PAUDIA, 1 (1), 91-105.

Kuswanto, C. W. (2016). Menumbuhkan Kemandirian Anak Usia Dini Melalui Bermain. Jurnal Ilmiah Pendidikan Islam Anak Usia Dini, 1 (2), 20-34.

Magta, M. (2013). Konsep Pendidikan Ki Hajar Dewantara Pada Anak Usia Dini, Jurnal Pendidikan Usia Dini, 7 (2), 221-232. doi: https://doi.org/10.21009/JPUD.0 72

Mayar, F. (2013). Pekembangan Sosial Anak Usia Dini Sebagai Bibit Untuk Masa Depan Bangsa. Jurnal Al-Ta'lim, 1 (6), 459464.

doi: 
Novia Rahmadianti. PEMAHAMAN ORANG TUA MENGENAI URGENSI BERMAIN DALAM MENINGKATKAN PERKEMBANGAN SOSIAL ANAK USIA DINI. Early Childhood : Jurnal Pendidikan. Vol. 4 No. 1, Mei 2020

http://dx.doi.org/10.15548/jt.v20 i3. 43

Mu'min, S. A. (2013). Teori Perkembangan Kognitif Jean Piaget. Jurnal Al-Ta'dib, 6 (1), 89-99.

Novita, D., Amirullah., \& Ruslan. (2016). Peran Orang Tua dalam Meningkatkan Perkembangan Anak Usia Dini di Desa Air Pinang Kecamatan Simeulue Timur. Jurnal Ilmiah Mahasiswa Pendidikan Kewarganegaraan Unsiyah, 1 (1), 22-30.

Novrinda., Kurniah, N., \& Yulidesni. (2017). Peran Orang Tua dalam Pendidikan Anak Usia Dini Ditinjau Dari Latar Belakang Pendidikan. Jurnal Potensia, PG-PAUD FKIP UNIB, 2 (1), 39-46.

Pebriana, P. H. (2017). Analisis Penggunaan Gadget Terhadap Kemampuan Interasi Sosial pada Anak Usia Dini. Jurnal Obsesi: Jurnal Pendidikan Anak Usia Dini, 1 (1), 1-11. doi: https://doi.org/10.31004/obsesi.v $1 \mathrm{i} 1.26$

Perdana, P. A. (2014). Peningkatan Keterampilan Sosial Anak Melalui Permainan Tradisional. Jurnal Pendidikan Usia Dini, 8 (1), 129-136.
Pratiwi, W. (2017). Konsep Bermain Pada Anak Usia Dini. Tadbir: Jurnal Manajemen Pendidikan Islam, 5 (2), 106-117.

Pujiati, D. (2015). Peningkatan Keterampilan Sosial Melalui Metode Bermain Peran. Jurnal Ilmiah Pendidikan Dasar, 7 (1), 1-15.

Pujiati, D. (2015). Peningkatan Keterampilan Sosial Melalui Metode Bermain Peran. DINAMIKA Jurnal Ilmiah Pendidikan Dasar, 7 (1), 1-15.

Rohmah, N. (2016). Bermain dan Pemanfaatannya Dalam Perkembangan Anak Usia Dini. Jurnal Tarbawi, 13 (2), 28-35.

Setiawan, M. H. Y. (2016). Melatih Keterampilan Sosial Anak Usia Dini Melalui Permainan tradisional. Jurnal Dimensi Pendidikan dan Pembelajaran, 5, 1-8.

Siska, Y. (2011). Penerapan Metode Bermain Peran (Role Playing) Dalam Meningkatkan Keterampilan Sosial dan Keterampilan Berbicara Anak Usia Dini, (2), 31-37.

Trinova, Z. (2012). Hakikat Belajar dan Bermain Menyenangkan Bagi Peserta Didik. Jurnal Al-Ta'lim, 1 (3), 209-215. 